Research article

\title{
Solanum sisymbriifolium Lam. (Solanaceae): A new addition to the flora of Odisha, India
}

\author{
S. C. Sahu, M. R. Mohanta* and A. K. Biswal
}

Department of Botany, North Orissa University, Baripada-757003, Odisha, India

*Corresponding Author: manasranjan.mrm@gmail.com

[Accepted: 15 December 2017]

\begin{abstract}
During the exploration of invasive flora in the northern part of Odisha, Solanum sisymbriifolium Lam. was collected from Rupsa of Balasore district. After reviewing its distribution through flora and available literatures, the species is found to be a new one to the Flora of Odisha. A detailed description with photographs, distribution, occurrence and phenology of the taxon are provided for easy identification.
\end{abstract}

Keywords: Solanaceae - Solanum sisymbriifolium - New record - Odisha.

[Cite as: Sahu SC, Mohanta MR \& Biswal AK (2017) Solanum sisymbriifolium Lam. (Solanaceae): A new addition to the flora of Odisha, India. Tropical Plant Research 4(3): 468-470]

\section{INTRODUCTION}

Solanum L. is a large and diversified genus belonging to family Solanaceae possessing more than a thousand numbers of species distributed throughout the world (Bohs \& Olmstead 1997). Family Solanaceae has a number of widely used drug plants such as Nicotiana tabacum L., Datura spp. and Atropa belladonna L. in India. The genus Solanum also has global importance for its food crops such as Solanum melongena L., Solanum tuberosum L., Solanum lycopersicum L. etc. This genus constitutes many economically important species widely distributed throughout tropical and temperate regions, with centers of diversity in Central and South America and Australia (Edmonds 1978, D’Arcy 1991). In India, the genus Solanum is represented by 42 species. A total of 9 wild and 3 cultivated species of Solanum have been reported in Flora of Orissa (Saxena \& Brahmam 1994-96). S. sisymbriifolium is distributed mostly in the southern part of India and also it has been reported in Jharkhand (Panda et al. 2014), Uttar Pradesh (Srivastava et al. 2015), Delhi (Mishra 2015), Bihar (Mishra \& Kumar 1992), Rajasthan (Yadav \& Menna 2007) and Tripura (Saha \& Datta 2013). However, Solanum sisymbriifolium has not been reported so far from the state of Odisha. With the addition of this newly recorded species, the total number of Solanum wild species in Odisha is increased to ten.

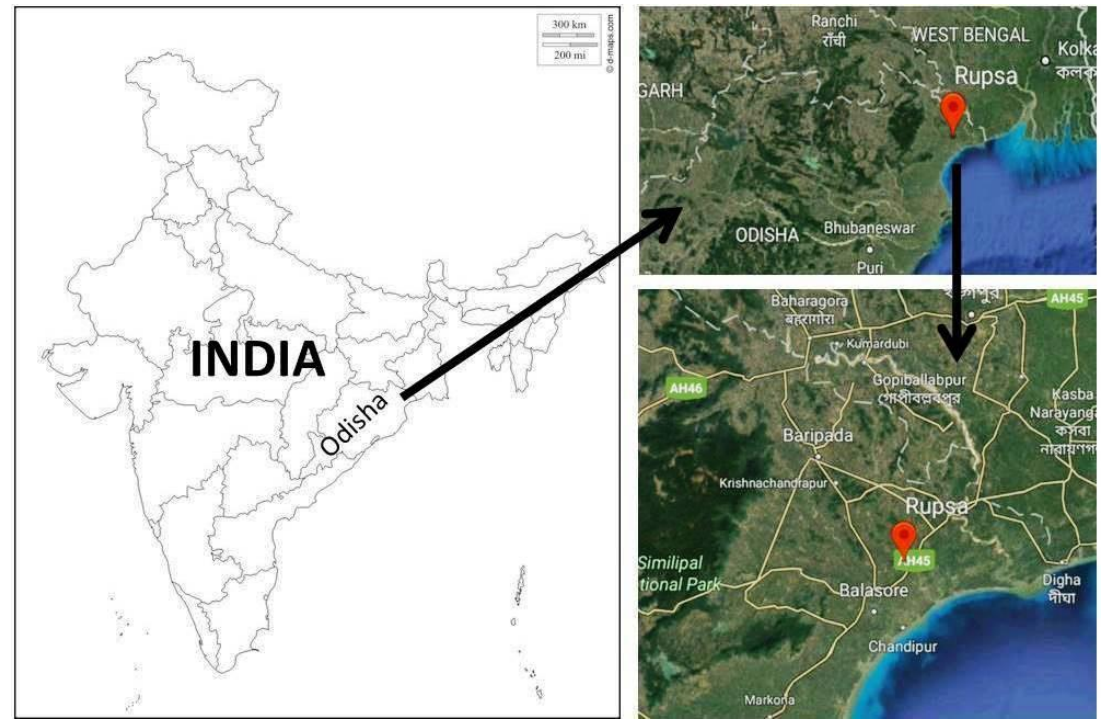

Figure 1. Map showing the collection site in Odisha. 
During July 2017, few specimens belonging to genus Solanum are collected near Rupsa railway station, Balasore district of Odisha (Fig. 1). Rupsa railway station is situated at $21^{\circ} 37^{\prime} 21^{\prime \prime} \mathrm{N}$ longitude and $87^{\circ} 01^{\prime} 09^{\prime \prime} \mathrm{E}$ latitude. After critical identification and consultation with the Flora of Orissa (Saxena \& Brahmam 1994-1996), it was found different from the Solanum species recorded for the state. The phenology, distribution, habitat, ecology are observed at the same locality. The specimens were verified with other published Solanum literatures (Deb 1983, Hooker 1885, Prain 1903, Kanjilal et al. 1939, Shetty \& Singh 1991, Almeida 2001). Finally, the specimens are identified as Solanum sisymbriifolium Lam. with consultation of herbarium at CAL (Central National Herbarium, Kolkata). The voucher specimens are preserved in the herbarium of Botany Department, North Orissa University, Baripada.
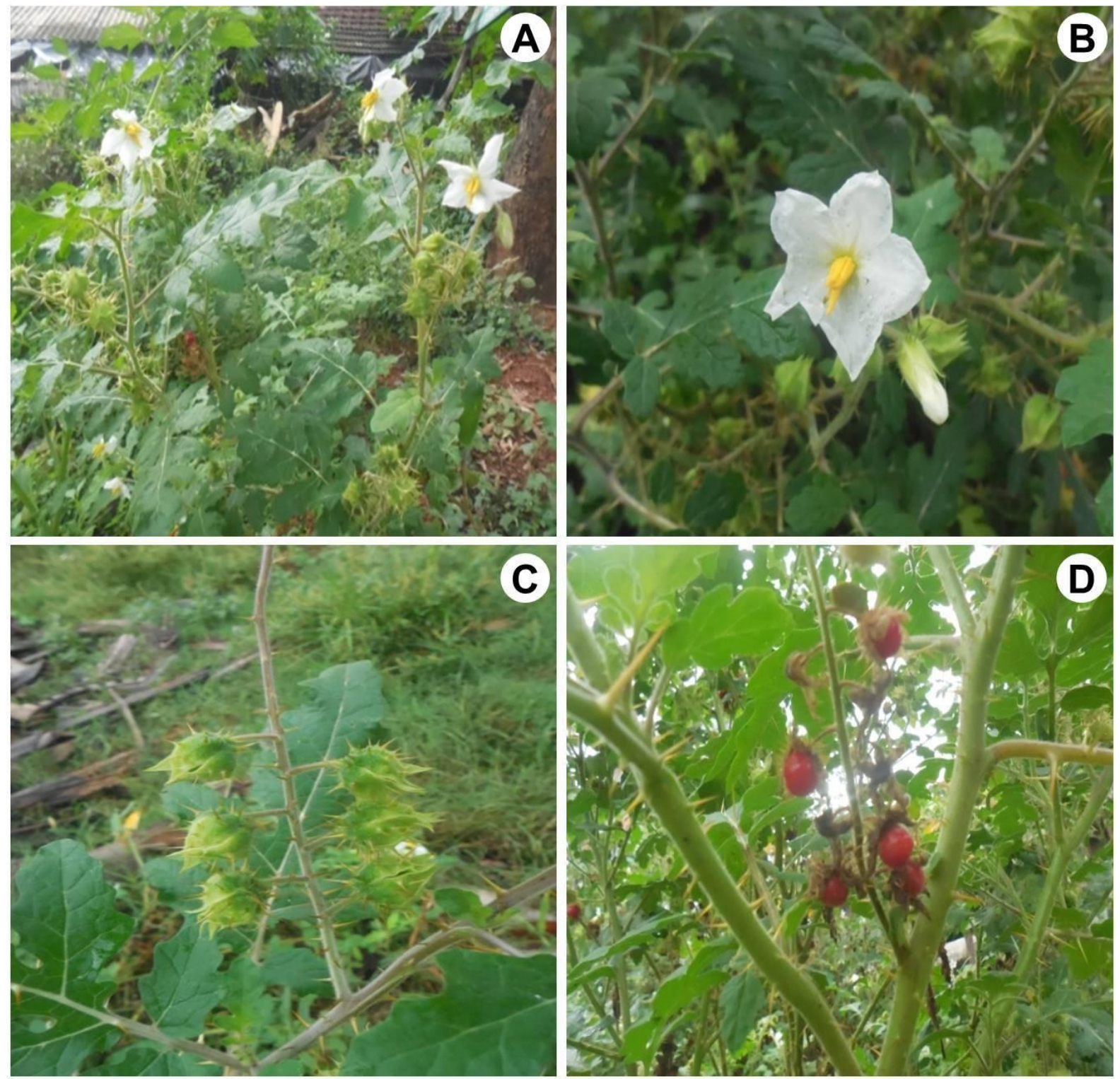

Figure 2. Solanum sisymbriifolium Lam.: A, Plant in natural habitat (Habit); B, A flower twig; C, Unripe berry (fruit); D, Ripe berry and prickles.

\section{DESCRIPTION OF THE SPECIES}

Solanum sisymbriifolium Lam., Tabl. Encycl. 2: 25. 1794.

(Fig. 2)

Solanum sisymbriifolium $\mathrm{f}$. lilacinum Kuntze

Perennial under shrub with maximum height of 2 meter. Stem sub erect or scandent with glandular hairs and prickled throughout. Prickles up to $15 \mathrm{~mm}$ long, yellow in colour and sharped. Leaf alternate, lamina ovateoblong, 9-16 × 4-11 cm, deeply lobed, pinnatified with many prickles along main veins on both surfaces with sparsely stellate hairs, wavy margin. Inflorescence racemose, 5-10 flowered. Peduncle $\mathrm{ca}$. $20 \mathrm{~cm}$ long, hairs glandular and simple. Pedicel $c a .1 \mathrm{~cm}$ long, slender and slightly prickly. Flower white, small, actinomorphic. 
Calyx cup-shaped, $9 \times 3 \mathrm{~mm}$, deeply 5-parted, green, prickly. Corolla white or slightly bluish, 35-45 mm in diameter, rotate, stellate, lobes triangular. Stamens 5, exserted, yellow, filaments reduced, slender, glabrous, $c a$. $0.2 \mathrm{~cm}$ long, anthers $0.7-0.8 \mathrm{~cm}$ long attached to petals. Ovary ovoid, $0.2 \mathrm{~cm}$, superior, glabrous; style $1.3 \mathrm{~cm}$ long. Fruiting pedicels deflexed with acrescent calyx, densely glandular- pilose and viscid, fruiting calyx enlarged 1.1-1.3 × 0.4-0.7 cm, enveloping most berry. Berry bright red, globose, 0.6-1.4 cm. diameter. Seeds reniform, ca. $0.2 \mathrm{~cm}$ diameter.

Flowering \& Fruiting: June-September.

Habitat: The species grows on waste places, roadsides, landfills and ploughed fields.

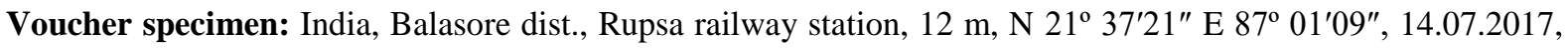
M.R. Mohanta et al.1562 (NOU).

Global distribution: This species is a native of Central and South America (Argentina, Southern Brazil, Paraguay, Uruguay, Bolivia and Colombia) and introduced in North America (Canada, Mexico, the United States), Europe (Spain, the Netherlands), Asia (India, China, Taiwan), Africa (South Africa, Congo, Swaziland), and Australasia (Australia, New Zealand).

Indian distribution: Andhra Pradesh, Assam, Bihar, Kerala, Karnataka, Maharashtra, Manipur, Orissa, Jharkhand, Punjab, Sikkim, Tripura Uttar Pradesh and West Bengal.

\section{ACKNOWLEDGEMENT}

The authors are thankful to the Head of Department Botany, North Orissa University, Baripada for providing infrastructure facility.

\section{REFERENCES}

Almeida MR (2001) Flora of Maharashtra. Orient Press, Mumbai III (B), pp. 373-382.

Bohs L \& Olmstead RG (1997) Phylogenetic relationships in Solanum (Solanaceae) based on ndhF sequences. Systematic Botany 22: 5-17.

D’Arcy WG (1991) The Solanaceae since 1976, with a review of its Biogeography. In: Hawkes JG, Lester RN, Nee M \& Estrada N (eds) Solanaceae III: taxonomy, chemistry and evolution. Academic Press, London, pp. 75-137.

Deb DB (1983) The Flora of Tripura State. Today and Tomorrow's Printers and Publishers, New Delhi, 601 p.

Edmonds JM (1978) Solanaceae. In: Heywood VH (eds) Flowering plants of the World. Oxford University Press, Oxford, pp. 228-229.

Hooker JD (1885) Flora of British India. Authority of the Secretary of State for India in Council, pp. 229-237.

Kanjilal UN, Kanjilal PC, Das A \& Dey RN (1939) Flora of Assam. Shillong Government Press, Shillong, 593 p.

Mishra AK (2015) Solanum sisymbriifoliumlam. - A new record for Delhi flora. Indian Journal of Plant Sciences 4(4): 53-56.

Mishra KK \& Kumar D (1992) Note on the occurrence of Solanum sisymbriifolium Lamk. (Solanaceae) in Bihar. Journal of Economic \& Taxonomic Botany 16(3): 562-564.

Panda SP, Sahoo HK, Sahu AK \& Subudhi HN (2014) Solanum sisymbriifolium Lam. - An addition to the flora of Jharkhand, India. Journal of Bombay Natural History Society 111(2): 147-148.

Prain D (1903) Bengal Plants. Botanical Survey of India, Calcutta, II 654 p.

Srivastava S, Dvivedi A \& Shukla RP (2015) Solanum sisymbriifolium Lam. (Solanaceae): A new invasive undershrub of the old-fields of north eastern Uttar Pradesh. Check list 11(3): 1643.

Saxena HO \& Brahmam M (1994-1996) Flora of Orissa, Vol- I-IV. Orissa forest department corporation Ltd., India.

Saha M \& Datta BK (2013) New distributional record of Solanum sisymbriifolium Lamarck (Solanaceae) from Tripura, India. Pleione 7(2): 579-582.

Shetty BV \& Singh V (1991) Flora of Rajasthan. Botanical Survey of India, Calcutta, pp. 571-576.

Yadav BL \& Meena KL (2007) Solanum sisymbriifolium Lam. (Solanaceae): A new record for Rajasthan, India. Journal of Economic \& Taxonomic Botany 31(3): 749-753. 